\title{
UBE2O wt Allele
}

National Cancer Institute

\section{Source}

National Cancer Institute. UBE2O wt Allele. NCI Thesaurus. Code C150022.

Human UBE2O wild-type allele is located in the vicinity of $17 q 25.1$ and is approximately $64 \mathrm{~kb}$ in length. This allele, which encodes (E3-independent) E2 ubiquitin-conjug ating enzyme protein, plays a role in protein monoubiquitination. 